\title{
SPECIFICS OF EDUCATIONAL FIELD MAN AND THE WORLD OF WORK IN RELATION TO THE POTENTIAL FOR DEVELOPING DIGITAL LITERACY
}

\author{
Jan Krotk $\boldsymbol{y}^{*}$, Západočeská univerzita v Plzni, Česká republika
}

Přijato: 21. 8. 2017 / Akceptováno: 11. 11. 2017

Typ článku: Teoretická studie

DOI: $10.5507 /$ jtie.2017.026

Abstract: Economic changes reflects the possibilities of implementing innovative methods and processes in technical education at primary schools in the Czech Republic, considering the development of digital literacy. The practical examples and tasks for pupils from the implemented international projects MaSciL (Mathematics and Science for Life) and WoW (World of Work) demonstrate the implementation of the research process and inquiry-based instruction. The multidisciplinary approach to the educational area World and Work is supported by the results of the international survey aimed on comparing the contents of educational plans in the Czech Republic, Slovakia and Germany.

Key words: World of Work, Technical education, Digital literacy, Inquiry-based instruction.

\section{SPECIFIKA VZDĚLÁVACÍ OBLASTI ČLOVĚK A SVĚT PRÁCE Z HLEDISKA POTENCIÁLU PRO ROZVOJ DIGITÁLNÍ GRAMOTNOSTI}

Abstrakt: Autor v článku determinuje ekonomická východiska pro transformaci školství obecně, $i$ z perspektivy vzdělávaci oblasti Člověk a svět práce. Analyzuje implementaci inovativnich metod a postupu do technického vzdélávání na základnich školách $v$ České republice s ohledem na rozvoj digitální gramotnosti. Na praktických př́kladech a úlohách pro žáky z realizovaných mezinárodních projektů MaSciL (Mathematics and Science for Life) a World of Work ukazuje implementaci výzkumného procesu a badatelské výuky. Pojetí vzdělávaci oblasti Člověk a svět práce je podloženo výsledky mezinárodního šetření.

Klíčová slova: člověk a svět práce, technické vzdělávání, digitální gramotnost, badatelská výuka.

*Autor pro korespondenci: conor@kmt.zcu.cz 


\section{1 Úvod}

Mylně se někteří učitelé z praxe domnívají, že vnější tlaky v podobě většího důrazu na rozvoj digitální gramotnosti budou mít za důsledek větší využívání počítačůn, tabletů a telefonů při vyučování. Obávají se právem o ,zdravi“ svěřených dětí, protože si zároveň uvědomují mentální, somatická i společenská rizika, která tyto technologie provází. V roce 2014 vyšla kniha Manfreda Spitzera (2014) s názvem Digitální demence, která upozornila na některé pedagogicko psychologické jevy, které provází využivání digitálních technologií. Mimo jiné tato kniha rozpoltila načas pedagogickou veřejnost, i když jejím cílem bylo naopak prezentovat a hledat na praktických prríkladech východiska.

Primárním cílem této studie je ukázat na konkrétních příkladech, kde by mohl být v tak komplexní vzdělávací oblasti jako je Člověk a svět práce prostor pro rozvoj digitální gramotnosti a informatického myšlení. Dále chceme rozptýlit obavy praxe, že by tento prostor mělo vyplnit pouze ,častější využívání“ digitální techniky. Druhým cílem je sumarizovat ekonomická a pedagogická východiska pro probíhající inovaci kurikula vzdělávací oblasti Člověk a svět práce. Tato vzdělávací oblast je typická svým výrazným pracovním a praktickým pojetím a má přímý vliv na ekonomický úspěch naší společnosti v budoucnu (např. volba povolání, vedení domácnosti atd.)

Samotnou badatelskou činnost, jejímiž výsledky chceme naplnit definované cíle, můžeme rozdělit do třech fází:

V první fázi průzkumu využíváme metod analýzy dokumentu aplikované na stěžejní dokumenty popisující aktuální stav ekonomiky ČR v oblasti zaměstnanosti a konkurenceschopnosti. Preferujeme analýzy Ministerstva práce a sociálních věcí a Českého statistického úřadu. Nicméně je pro nás důležitý i názor odborníků a organizací, které jsou prezentovány profesními mediálními kanály pro případnou komparaci našich názorů a postojů.

Druhá fáze je mezinárodní rešerší teoretických přístupů k rozvoji digitální gramotnosti, kde zároveň vymezujeme pojmy a specifika některých př́stupů. Realizací této fáze získáme potřebný teoreticko-vědecký přesah pro správnou identifikaci zkoumaných jevů a procesů ve fázi třetí.

Třetí fáze průzkumu se soustředí na identifikaci potenciálu pro rozvoj digitální gramotnosti, potažmo informatického myšlení v konkrétních edukačních př́kladech.

Objektem analýzy jsou soubory námětů, aktivit a činností splňujících uvedené předpoklady:

1. Spadají svým přesahem do vzdělávací oblasti Člověk a svět práce,

2. v rámci jejich řešení vznikly nové vzdělávací materiály, nové úlohy přímo pro žáky,

3. prezentované náměty a aktivity byly evaluovány v praxi,

4. obsahují více námětů a aktivit, i vzájemně propojených,

5. byly realizované v našem národním prostředí nebo blízkém.

Záměrným výběrem volíme dva projekty. Celoevropský projekt MaSciL (Mathematics and Science for Life) a Projekt World of Work (Svět práce) slovenského nakladatelství Dr. Josef Raabe s.r.o. 


\section{Ekonomická potřeba transformace}

Česká republika má v rámci zemí Evropské unie (EU) jedno specifikum. Tím je vysoký podíl zaměstnanosti v rámci sekundárního sektoru, tedy průmyslu a stavebnictví. V Česku se jedná o hodnotu asi $36 \%$ proti $22 \%$ zbytku evropské osmadvacítky. V oblasti terciární (služby) je tento poměr opačný. ČR $60 \%$ a zbytek EU jako celek přibližně $74 \%$ (MPSV, Analýza vývoje zaměstnanosti, 2015). Zajímavé je, že tuto „čelní“ pozici zastáváme spolu s Polskem a Slovenskem. Pro úplnost v podílu zaměstnanosti v sektoru primárním (zemědělství) prakticky nezaostáváme (ČR 3,3\% a EU 4,8\%).

Vysoký podíl zaměstnanosti a výkonosti ve službách je určitým znakem rozvoje ekonomiky. Podíváme-li se na strukturu ekonomiky ČR z hlediska hrubé přidané hodnoty, zjistíme, že například v porevolučním roce 1990 se služby podílely na ekonomice asi z $46 \%$. V roce 2014 už tento údaj byl $60 \%$. Změna proběhla pochopitelně na úkor sekundárního a hlavně primárního sektoru. (ČSU, 2015)

Musíme si však uvědomit, že v případě snižování podílu průmyslu na ekonomice, a tedy neprrímo i zaměstnanosti ve vyspělých zemích EU existují i další faktory. Zejména se jedná o transport průmyslu směrem na východ za nižšími náklady a udržování výroby hlavně produktů s vysokou přidanou hodnotou. Jedněmi z nejvyšších nákladů při výrobě bývají náklady na mzdy pracovníků. Aktuální stav v České republice z hlediska porovnání úrovně mezd mezi ekonomikami dobře vystihuje vyřazení ČR ze skupiny vyspělých zemí. „Banka JPMorgan vyřadi Českou republiku ze skupiny vyspělých zemí. Nově ji zařadí do skupiny emerging markets. Dưvodem je výše př́jmu na hlavu, která se poslední tři po sobě jdoucí roky pohybuje pod úrovní stanovenou pro vyspělé země." (Němeček, 2017)

Dalším faktorem, který má negativní vliv na zaměstnanost v sektoru průmyslu, je zvyšování produktivity práce implementací efektivnějších postupů a nových technologických procesů. Respektive tento proces můžeme charakterizovat jako vyšší podíl práce strojů a automatizace dosud ručně prováděných operací. Národní vzdělávací fond, o.p.s., predikuje pokles zaměstnanosti mezi roky 2010 a 2020 zejména u následujících oborů: textilní a oděvní průmysl 31\%, hornictví a slévárenství 29\%, výroba stavebních hmot a kovodělných výrobků $20 \%$. Naproti tomu očekává dynamický rozvoj v oblastech jako jsou především služby: podnikatelské služby $28 \%$, zdravotní a sociální služby $18 \%$, vzdělávání $8 \%$. V oblasti průmyslu můžeme očekávat posun zejména v ICT sektoru $38 \%$ nebo u výroby speciálních elektrických př́strojů a automatizační techniky $8 \%$. (Braňka, 2010)

Naznačili jsme zjednodušeně polemiku transportu průmyslu $\mathrm{v}$ tom klasickém výrobním pojetí směrem od vysoce rozvinutých zemí k těm méně rozvinutým nebo ještě lépe k těm, které se takto rozvíjet nechají. Vladimír Mařík a jeho kolektiv (2015) ve své publikaci Národní iniciativa Průmysl 4.0 uvádí jeden zajímavý postřeh: „Nestojíme na prahu čtvrté průmyslové revoluce, ona již totiž započala. Započala v nejrozvinutějšich světových ekonomikách, sice pod různými názvy, ale vedena stejnou snahou, a to snahou o udrženi a posileni konkurenceschopnosti a technologického prvenství těchto států na světových trzích. Snahou o převzetí větši kontroly nad celým hodnotovým řetězcem, což je za současného stavu ceny pracovní sily a její dostupnosti v těchto zemích velmi obtižné." (Mařík a kol., 2015) Tato věta přesně vystihuje nový model průmyslové výroby a je jen otázkou, kde jako národ chceme stát. Průmysl 4.0 není tedy o pouhé digitalizaci, ale je zejména o transformaci a integraci nejen výrobních procesů, o udržení konkurenceschopnosti, o transformaci výzkumu, infrastruktury a hlavně vzdělávání. Vláda 
České republiky $\mathrm{k}$ této komplexní změně připravuje celou řadu akčních plánů jak problematiku řešit na celé řadě úrovní, od kybernetické bezpečnosti, dopravy, fiskálních nástrojů, rozvoje lidských zdrojů, výzkumu a vzdělávání atd. (Mařík a kol., 2015)

Jak zde bylo naznačeno, výzvu Průmysl 4.0 můžeme chápat i jako závod. Naši silnou stránkou jou průmyslové tradice naší země, vztah $\mathrm{k}$ technice a pracovní morálka. Slabou stránkou je flexibilita legislativy, její komplikovanost vzhledem $\mathrm{k}$ aplikovatelnosti a vymahatelnosti a účinný transfer vědeckých výstupů do praxe. Naše republika je součástí Evropské unie, musíme si však položit otázku, zda nehrajeme již ted' v rámci společenství čím dál častěji tzv. druhé housle.

Strategie politiky zaměstnanosti do roku 2020 Ministerstva práce a sociálních věcí připomíná v návaznosti na uváděné změny některé zásadní neduhy našeho školství: „V současné době však počáteční vzdělávání, s ohledem na dynamiku ekonomického systému a technologického rozvoje, nemá možnost poskytnout dostatečné kompetence jedinci na celou dobu jeho profesního života. Zároveñ se český vzdělávaci systém potýká $s$ problémy $v$ oblasti nedostatečného rozvoje technického a učňovského vzděláváni a projevuji se problémy ve vazbě vzdělávacího systému na potřeby trhu práce." (MPSV, 2014). Revize kurikula na všech úrovních je nutná a nezbytná. Nicméně i probíhající transformace průmysl 4.0 není orgány moci $\mathrm{v}$ současné době jednoznačně pojatá a v některých ohledech můžeme vývoj pouze rámcově predikovat. Dle našeho názoru by měla inovace rámcových vzdělávacích programů základního školství respektovat dynamiku systému a nabídnout variabilitu. Samozřejmě při zachování inovovaných úrovní požadavků a definic výstupů. Tyto výstupy a požadavky musí korespondovat s požadavky, které nám definuje praxe nebo lépe praktické pojetí života a životní situace. Můžeme např́klad polemizovat o správnosti nebo nastavení tzv. duálního vzdělávání, kdy se na procesu vzdělávání podílí i firma, pro kterou se pak daný žák připravuje. Systém duálního vzdělávání př́mo vychází z konkrétní praxe, konkrétního oboru a konkrétního podniku. Absolvent je tedy specialista, ale v relativně úzkém oboru. Což může být problematické $\mathrm{z}$ hlediska jeho adaptace na nové podmínky a změny, které přináší praxe. Vzpomeňme např́klad na problematiku rekvalifikací propouštěných horníků z dolů OKD v posledních letech.

K inovaci vzdělávání dochází i na vysokých školách. Jsou akreditovány nové obory, které reflektují technologický vývoj, obory a předměty směřované do mechatroniky, nanomateriálů, ř́zení a provozu dronů atd. Vysoké školy se zapojily do projektu Q-Ram „Národní kvalifikační rámec terciárního vzdělávání“, jehož jedním z cílů je propojení počátečního a dalšího vzdělávání a propojení praxe. Tedy definovat např́klad výstupy učení jednotlivých oborů, ale i předmětů, inovovat vzdělávací programy a maximálně zefektivnit proces výuky. $\mathrm{V}$ nadcházejícím období bude pro rozvoj průmyslu další vzdělávání absolventů a potažmo zaměstnanců klíčové. Ministerstvo práce a sociálních věcí k problematice dalšího vzdělávání uvádí: „Dalši vzdělávání je účinným nástrojem pro budováni trvalého rozvoje národniho hospodářství a posilování adaptability pracovni sily na ménicí se podminky.“ (MPSV, 2014)

Kritické myšlení, tvořivost, komunikace a spolupráce jsou zásadními kompetencemi pro dnešní uplatnění na trhu práce a budou mít stále silnější váhu v budoucnosti. (Teichler, 2009) 


\section{Digitální vzdělávání, digitální gramotnost}

Digitální gramotnost jako pojem zmiňuje už v roce 1997 Paul Gilster (1997) ve své publikaci Digital literacy. Samotný pojem digitální ve vztahu ke vzdělávání, gramotnosti nebo dovednostem je v českém jazyce mírně zavádějící. Název je odvozen od anglického pojmu digit, což je číslice nebo také výraz pro prst. Digitální znamená nespojitý. Opakem je spojitý, tedy analogový. Ovšem v souvislosti s dovednostmi nebo vědomostmi je původní pojetí takto nepoužitelné. Jelikož nemůžeme uvažovat samotnou podstatu slova v jeho původním pojetí, je třeba pochopit nový rozměr slova digitální v souvislosti se současným vývojem. O digitálním vzdělávání tedy můžeme mluvit jako integrujícím prvku vzdělávání zahrnujícím moderní technologie na všech úrovních poznávání. „Digitální gramotnost nebo digitální kompetence nejsou pouhou syntézou schopností a instrumentálních znalostí, ale predstavuji spišse komplexní integraci mezi kognitivními procesy a dimenzemi ..." (Calvani a kol., 2008) Nutno podotknout, že Calvanim (2008) zmiňované dimenze vychází z vlastního rámce digitálních kompetencí.

V Norsku v první polovině 90 . let byla např́klad mediální výchova kurikulárně oddělená od technického vzdělávání (počítače byly tehdy v počátcích). Ovšem asi o deset let později už kurikulární reforma v Norsku zakotvila digitální gramotnost jako jednu z hlavních kompetencí a zároveň ji definovala vedle základních dovedností, kterými jsou čtení, psaní a počítání, jako schopnost využivat digitální nástroje. (Sefton-Green a kol., 2009) $Z$ tohoto př́ikladu je patrná rychlost, s jakou změny přichází a že se nejedná v zásadě o novou problematiku či nové trendy. Je zde patrné také integrační pojetí digitální gramotnosti, která zároveň stojí na stejné úrovni jako gramotnosti ostatní, ale svou podstatou je propojuje.

Následující tabulka (Tab. č. 1) vystihuje požadavky na vzdělávání v 21. století s ohledem na transformaci pracovního trhu a implementaci nových technologií.

\begin{tabular}{|c|c|c|}
\hline \multicolumn{3}{|c|}{ Dovednosti pro 21. století } \\
\hline $\begin{array}{l}\text { Základní gramotnosti } \\
\text { Jak studenti aplikují } \\
\text { základní dovednosti na } \\
\text { každodenní úkoly }\end{array}$ & $\begin{array}{l}\text { Kompetence } \\
\text { Jak studenti přistupuji ke } \\
\text { složitým výzvám }\end{array}$ & $\begin{array}{l}\text { Charakterové vlastnosti } \\
\text { Jak se studenti přibližuji } \\
\text { měnícímu se prostředí }\end{array}$ \\
\hline $\begin{array}{ll}\text { - } & \text { Čtenářská } \\
& \text { gramotnost } \\
\text { - } & \text { Matematická } \\
& \text { gramotnost } \\
\text { - } & \text { Vědecká } \\
& \text { gramotnost } \\
\text { - } & \text { ICT gramotnost } \\
\text { - } & \text { Finanční } \\
\text { - } & \text { gramotnost } \\
\text { Kulturní a } \\
\text { občanská } \\
\text { gramotnost }\end{array}$ & $\begin{array}{ll}\text { - } & \text { Kritické } \\
& \text { myšlení / } \\
\text { řešení } \\
& \text { problémů } \\
\text { - } & \text { Tvořivost } \\
\text { - } & \text { Komunikace } \\
\text { - } & \text { Spolupráce }\end{array}$ & $\begin{array}{ll}\text { - } & \text { Zvědavost } \\
\text { - } & \text { Iniciativa } \\
\text { - } & \text { Vytrvalost } \\
& \text { odhodlání } \\
\text { - } & \text { Přizpůsobivost } \\
\text { - } & \text { Schopnost vést } \\
& \text { lidi } \\
\text { - } & \text { Sociální a } \\
& \text { kulturní } \\
& \text { povědomí }\end{array}$ \\
\hline
\end{tabular}

Tab. č. 1: New Vision for education, World Economic Forum 2016, převzato a upraveno. 
Není předmětem tohoto článku rozebírat jednotlivé gramotnosti, ovšem uvedeme alespoň některá specifika a směry. Může se zdát, že čtenářská gramotnost neprochází v průběhu času vývojem. Opak je ale pravdou. Zásadně se např́klad změnila forma textu a médium, kterým je text přenášen. Strategií čtení digitálního textu a jeho evolucí se zabývá např́klad K. Szabó (2016).

Uvedenou ICT gramotnost můžeme chápat opravdu jako informační gramotnost, tedy zjednodušeně jako schopnost efektivně pracovat s informacemi, ale zároveň v tomto pojmu můžeme vidět i gramotnost digitální v tom nejširším slova smyslu. Samotná ICT a její výuka by měla být integrována. Kurikulum ICT by nemělo být chápáno jako nástroj pro výuku a učení, ale jako nástroj pro rozvoj technických a dalších dovedností. (Vanderlinde, Braak, 2010)

Digitální kompetence můžeme sumarizovat do pěti oblastí (Ferrari, 2013):

1. Informace: identifikovat, lokalizovat, získávat, ukládat, organizovat a analyzovat digitální informaci a posuzovat jejich relevanci.

2. Komunikace: komunikovat v digitální prostředí, sdílet zdroje prostřednictvím online nástrojů, propojovat se s ostatními a spolupracovat prostřednictvím digitálních nástrojů, komunikovat v rámci komunit.

3. Vytváření obsahu: vytvářet nové a upravovat staré formy obsahu, využívat média, tvořit kreativně a dodržovat autorská práva.

4. Bezpečnost: ochrana dat a vlastní digitální identity, bezpečné využívání technologií a pohybu v digitálním světě.

5. Řešení problémů: využití digitálních zdrojů pro rozhodování, využití technologií pro řešení problémů, $\mathrm{k}$ identifikaci digitálních potřeb.

Být digitálně gramotný znamená mít znalosti a schopnosti efektivně pracovat, kriticky hodnotit a vytvářet informace pomocí širokého portfolia digitálních technologií. Digitálně gramotný člověk strategicky využívá technologie k nalezení a vyhodnocení informací, informace analyzuje a syntetizuje, spolupracuje s ostatními, a to vše za účelem dosažení profesních a osobních cílů. (Grech, 2014)

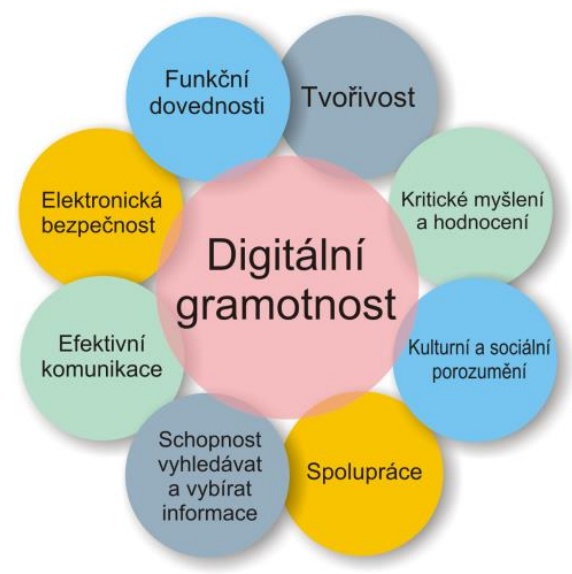

Obr. č. 1: Složky a průniky digitální gramotnosti (Eyre, 2017) prevzato a upraveno 
Obrázek 1 nám představuje digitální gramotnost v kontextu dalších pojmů či oblastí. Zde uvedené funkční dovednosti jsou reprezentovány jako základní dovednosti pro ovládání jazyka, matematiky a informačních a komunikačních technologií. „Funkčni dovednosti (Functional Skills) byly ve Velké Británii zavedeny v zářri 2010 a v říjnu 2012 oficiálně nahradily klíčové dovednosti (Key Skills)." (Forskills.co.uk) V zajímavém postavení je zde kulturní a sociální porozumění. Tuhle oblast můžeme v našem kontextu uchopit jako určité sociální situace a interakce v rámci komunity. Kulturní porozumění funguje jako nedílný aspekt efektivní komunikace v mezinárodním prostředí. Jde primárně o respektování odlišnosti jako takové. Těžko např́klad nějak výrazně uspěje podnikatel s myšlenkou dodávek vepřového do muslimských zemí apod.

\section{Směr transformace a inovace}

Hejnová a Hejna (2016) ve svém článku Rozvoj vědeckého myšlení žáků prostřednictvím prrírodovědného vzdělávání uvádějí s odkazem na studie TIMSS a PISA závažný, ale obecně známý problém. Čeští žáci jsou schopní naučit se fakta, ale nemají znalosti a dovednosti pro vlastní efektivní experimentování, komparaci a interpretaci dat nebo vytváření hypotéz. Zároveň autoři doporučují zaměřit se na aktivity, které rozvíjejí požadované a propojují fakta $s$ reálným životem. Jejich článek nám přináší komplexní studii i s praktickými př́klady jak implementovat badatelské metody ve vzdělávání a účinně tak rozvíjet vědecké myšlení žáků. „Ve všech přirodovědných oborech docházi k obrovskému nárůstu poznatkư, které neni možné jednoduchým způsobem převádèt do vzdělávacích predmětů. Neni totiž již dưležité pouze to, co se dozvidáme, ale také to, jak se dokážeme $v$ množstvi informací orientovat, jak umíme najít podstatné informace a jak je dokážeme zpracovat a použit." (Hejnová, Hejna, 2016) Vidíme, že orientace v informacích a jejich zpracování s porozuměním je pro vyšší úroveň poznání nezbytná. Rasinen a kol. (2009) identifikuje různé úrovně porozumění žáků při výuce techniky (pojmenovává jako technologické kompetence). Základní úroveň spočívá v porozumění samotným funkcím systémů. Dosažení druhé úrovně předpokládá u žáků porozumění, proč tyto technologie používáme, a poslední, nejvyšší úroveň je o aplikaci technologií. Samotná aplikace pak musí vycházet z řešení konkrétní situace, problémové úlohy, experimentu atd. (Rasinen a kol., 2009) Poslední úroveň je pochopitelně v procesu nejdůležitější, ale nelze jí dosáhnout bez elementárních dílčích znalostí, které jsou součástí stupňů předchozích. Jak udává Hejnová a Hejna (2015), ,osvojení nižši dovednosti je předpokladem k osvojení vyšši dovednosti“ (Hejnová, Hejna, 2015). Zajímavé je porovnat koncept modelu Rasinen a kol. (2009) s třístupňovým modelem pro rozvoj digitální gramotnosti projektu Evropské komise DigEuLit (Digital Literacy, Malta, 2015):

1. Digitální kompetence - dovednosti, pojmy, postoje a př́ístupy.

2. Používání digitálních technologií - uplatnění digitálních kompetencí přímo v kontextu.

3. Digitální transformace - kreativita a inovace v digitální oblasti.

Praxe v českém školství ukazuje, že právě těchto posledních úrovní stále nedokážeme ve vzdělávacím procesu efektivně dosáhnout. Přitom např́iklad finské základní školy v ekvivalentu našeho 1. stupně dokáží pojmout v rámci výuky techniky nebo technologií celý výrobní proces: záměr, projekt, model, konstrukce i hodnocení. (Rasinen a kol., 2009) 
Na obrázku 2 je znázorněn upravený životní cyklus produktu směrem k produktu školnímu. Oproti komerčnímu schématu tento zjednodušený model neobsahuje závěrečnou komerční část (náklady, zisk a efektivitu výroby), kterou v prostředí základní školy obvykle nerealizujeme a zároveň značně zjednodušujeme část úvodní - prvotní problém (v komerčním prostředí bývá iniciován opět trhem). Obvykle tento problém v pedagogické praxi díky omezeným zdrojům pouze simulujeme. Nicméně jak jednotlivé fáze, tak i kategorie korespondují s reálným vývojem produktu a potažmo i se schématem výzkumného procesu a jsou př́kladem algoritmického postupu.

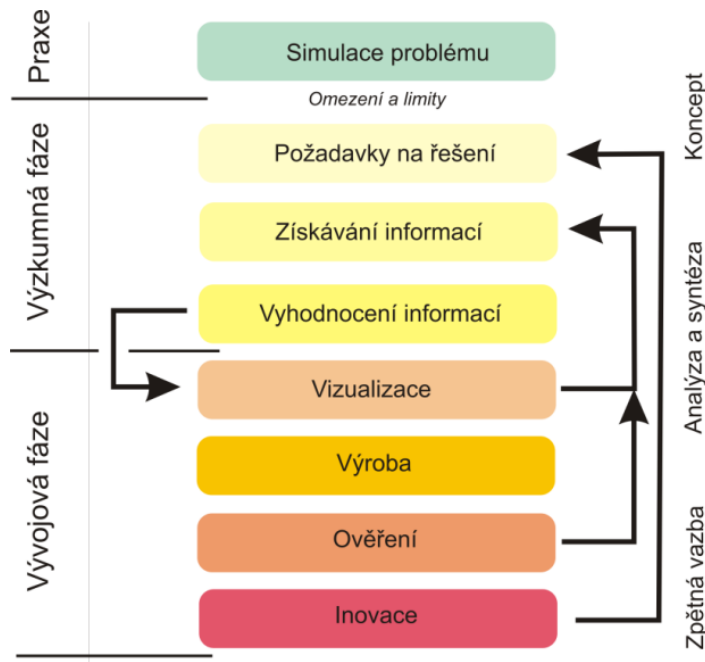

Komerčni fáze

Obr. č. 2: Životni cyklus školniho produktu s ohledem na jeho reálný vývoj

\section{5 Člověk a svět práce, specifika a proměny}

Rámcový vzdělávací program pro základní vzdělávání (RVP ZV), který je výchozím materiálem pro vzdělávání většinové společnosti, charakterizuje vzdělávací oblast Člověk a svět práce jako oblast, která ,postihuje široké spektrum pracovnich činností a technologií, vede žáky $k$ ziskáni základnich uživatelských dovedností v rưzných oborech lidské ćinnosti a prispiviá k vytvárení životní a profesni orientace žákư.. (NÚV, 2017) Dále se $\mathrm{v}$ charakteristice oblasti dočteme o tom, že obsah vychází z koncepce životních situací. Zajímavé je také zaměření oblasti, které je cíleno na praktické pracovní dovednosti a návyky. Právě praktické zaměření a multioborovost vzdělávací oblasti je její významnou charakteristikou, která se projevuje i v jisté specifičnosti metod pro dosažení klíčových kompetencí. (Bartoň, 2017)

Z praxe víme, že vzdělávací oblast Člověk a svět práce (ČSP) je $\mathrm{z}$ velké části vyučována $\mathrm{v}$ předmětech $\mathrm{s}$ názvy jako Technická výchova, Pracovní nebo Praktické činnosti. Situaci kolem transformace oblasti shrnuje Novák a Stebila (2016): „Od 
dvacátých let minulého století prošlo technické vzděláváni v základním školství několika etapami, $v$ jejich průběhu se výrazně měnily názory na obsah a funkci přislušných predmétů."

Ačkoliv můžeme tvrdit, že učivo zůstává dlouhodobě více méně stejné, nepočitaje migraci mezi oblastmi nebo okruhy, mění se pozvolna styl výuky a používané metody práce. $Z$ velké části se na inovacích a nových metodách výuky podílí nové technologie. Tímto nemyslíme pouze technologie prezentační, interaktivní a multimediální, ale zejména nové nebo znovuobjevené typy stavebnic, nové stroje a př́istroje a samozřejmě výpočetní technika. Nácvik pracovních nebo manuálních dovedností přestává být prioritou a klade se zvýšený důraz na proces zpracování informací, objevování a integraci s dalšími obory. Tato evoluce se odráží i ve vývoji metodických materiálů, kde existuje vysoká poptávka po nových a nově pojatých aktivitách a projektech. Zajímavé je, že tyto trendy nejsou úplně nové. V období charakterizovaném jako první republika (1918-1938) byly podobné tendence a můžeme si o nich přečíst naprííklad v dílech Jana Pastejříka (1937).

Následující graf 1 je sondou do oblasti Člověk a svět práce ve vzdělávacích programech ekvivalentních $\mathrm{k}$ českému RVP ZV. Data byla pořízena v rámci výzkumu projektu Erasmus + World of Work a sloužila jako prvotní rozhled před tvorbou československo-německé publikace s metodickými náměty pro tuto oblast. Nástrojem průzkumu byl dotazník sestavený německým partnerem a vyplňovaly jej instituce zainteresované v projektu. $Z$ výsledků je patrná multioborovost vzdělávací oblasti a to zejména $\mathrm{v}$ oblasti př́rodních věd. Za zmínku stojí i respondenty udaná vazba na vzdělávací oblast Člověk a jeho svět, kde i v českém RVP ZV existuje přesah v učivu (např. vlastnictví, současnost a minulost $\mathrm{v}$ našem životě, obecně práce $\mathrm{s}$ laboratorní technikou atd.)

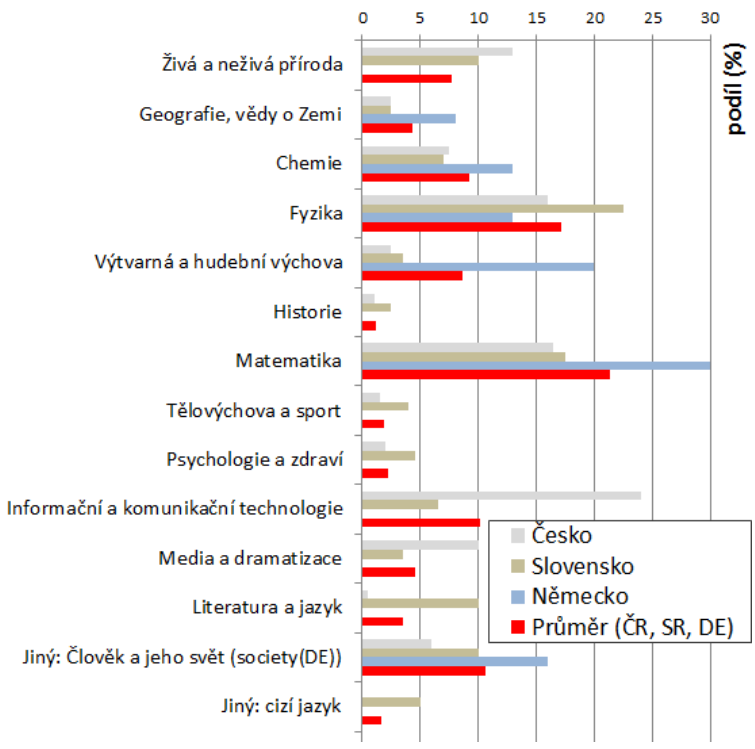

Graf č. 1: Podíl oborů na vzdělávaci oblasti Člověk a svět práce v Česku, Slovensku a Německu (Mach, Simbartl, Krotký, 2015) 


\section{Koncepty inovativních úloh - implementace řešení}

Představíme si dva projekty, respektive inovativní aktivity zpracovávané $\mathrm{v}$ rámci těchto projektů, které jsou v souladu s výše naznačovanými trendy - implementací výzkumného procesu a badatelské výuky do školní praxe a rozvoje digitální gramotnosti $\mathrm{v}$ širším integračním kontextu.

Projekt MaSciL (Mathematics and Science for Life) realizovaný v rámci celé Evropské unie v letech 2012 až 2016 si kladl za cíl zviditelnit vztah mezi matematikou a př́rodními vědami a reálným životem. „Žáci jakožto nastupující generace, která bude muset činit důležitá rozhodnutí, se musejí naučit využívat prírodní vědy a pochopit a ocenit výsledky a dopady, které mají na náš každodenni život a na svět, v němž žijeme." (Doorman at al., 2016)

Projekt MaSciL definuje možnost propojení úkolů pro žáky se světem práce na čtyřech úrovních (Doorman at al., 2016):

- $\quad$ kontext úlohy, který souvisí se světem práce,

- $\quad$ profesní role, kterou žáci v procesu zaujmou,

- $\quad$ aktivity, které odráží praxi v dané oblasti,

- $\quad$ produkt, který je výsledkem procesu.

„Aktivity pro žáky by se mély co nejvice podobat aktivitám reálných pracovníki̊ a využivat autentické pomi̊cky." (Doorman at al., 2016) Autoři ve své publikaci Matematika a př́rodní vědy pro život: badatelsky orientovaná výuka a svět práce (Doorman at al., 2016) představují proces transpozice strukturované verze úkolu pro žáky na verzi podporující badatelský př́stup a vazbu na svět práce. Klasická verze strukturovaného úkolu v jejich pojetí „Čištění solného roztoku“ se klasicky opírá o pracovní postup, definici materiálu a používaných surovin a hlavně přesnou definici prováděných úkoli̊. Inovovaná verze téže úlohy je naproti tomu uvozena informací zasazující úlohu do reálného kontextu a rámcově představující problém (,Jsi chemický inženýr a čerpáte vodu v oblasti XY a ta má parametry ..."), reálné pomůcky jsou žákům v úloze definovány a je ponechán prostor pro další jejich rozšíření. Tento prostor je pro žáky velice užitečný a účelný, nebot' jim poskytuje určité možnosti pro alternativní řešení úlohy. Autoři tedy zadali problém, definicí pomůcek prakticky doporučili řešení a definovali výstupy v podobě jednoduchých otázek.

Úloha projektu MaSciL na odhad počtu lidí v davu: „Žáci byli překvapeni, že každá skupina došla k jinému výsledku a učitelé je akceptovali. Důležitou vlastností tohoto úkolu byla jeho otevřenost - žáci sami vyhledávali potřebná data a zvažovali, která jsou potřebná.“ Žáci sami vyhodnotí potřebnost dat a navrhují způsob jejich pořízení, výběr i zpracování - jedná se tak o nenásilnou implementaci ICT do úlohy způsobem podporujícím digitální gramotnost. Zároveň autoři úlohy umožnili žákům kreativní řešení úlohy spočívající v reálném experimentu nebo i simulaci.

Další zajímavou úlohou pro žáky, která byla vytvořena a evaluována v rámci projektu MaSciL je aktivita s výrobou univerzální police. Police je klasickým tématem té „tradiční“ technické výchovy zaměřené primárně na manuální práci v dílně. Žáci obvykle dostávají od učitele připravené polotovary, nářadí, př́ípravky a hlavně přesný výkres pro montáž a sestavení finálního výrobku (Krátký, 2015). Evaluace produktu probíhá zejména kontrolou fyzických rozměrů a jejich komparací s požadavky. (Draxal, 2016) Takovéto pojetí praktického námětu slouží především k nácviku technologických operací a rozvoji 
manuálních dovedností, pomineme-li faktický přínos v podobě určitého rozvoje kompetencí v interpretaci grafické informace a dalších spíše okrajových záležitostí. Autoři aktivity „Vytvoř nestandardní polici“ postavili úlohu opět na otevřených formulacích úkolů. Úloha $\mathrm{v}$ jejich podání měla značný mezioborový přesah do matematiky, což je plně $\mathrm{v}$ souladu $\mathrm{s}$ mezioborovým pojetím moderního technického vzdělávání nejen na základních školách a s koncepcí STEM jako integračního faktoru. (Krotký, Korytár̆, Simbartl, 2016; Dostál, Prachagool, 2016). Takto pojatá úloha měla vysokou variabilitu řešení, rozvíjela matematické i informatické myšlení a výsledkem byl produkt. „V této fázi žáci zjistili, že pokud si vyberou mnohoúhelniky, jejichž úhly jsou násobky $30^{\circ}$ a strany všech mnohoúhelníkủ mají stejnou délku, pak mohou sestavit polici pouze ze dvou typü součástek“ (Doorman at al., 2016) Dle našeho názoru má větší potenciál pro rozvoj digitální gramotnosti, ale i manuálních dovedností, než jak ji realizovali v rámci projektu MaSciL v Rumunsku. Například univerzální spojovací díl desek police mohl být inovativním produktem samotných žáků. $\mathrm{K}$ jeho výrobě mohlo být kromě konvenčních nástrojů použito i počítačově řizených strojů. Tento rozšířený koncept by více prohloubil vazbu úlohy na reálnou praxi a zároveň by rozšíriil role žákovského realizačního týmu.

Z hlediska evaluace práce žáků můžeme v původním provedení úlohy (realizované v rámci projektu MaSciL) hodnotit zejména přístup a nasazení žákovského realizačního týmu, př́ípadně zapojení a aktivitu jednotlivých členů. Samotný fyzický výrobek sestavený z prefabrikátů umožňuje velké množství variant, ovšem z hlediska konstrukčního se jedná pouze o modifikace. Takto pojatý produkt nelze hodnotit podle úrovně a přesnosti zpracování, ale velice dobře jej můžeme hodnotit naprríklad z hlediska funkčního. (Callahan at al. 1995)

Projekt World of Work (Svět práce) je řešen od roku 2015 v rámci programu Erasmus + Strategická partnerství ve školním vzdělávání. Nositelem tohoto projektu je slovenská strana v podobě nakladatelství Dr. Josef Raabe. Aktivními řešitelem je zejména Západočeská univerzita v Plzni a Univerzita ve Stuttgartu. Na projektu participují také německé neziskové organizace zabývající se výukou STEM nebo slovenská střední škola designu. Evaluaci vytvářených námětů mají pod patronací dvě základní školy. Výstupem projektu je metodická prŕručka $\mathrm{s}$ novými nebo nově koncipovanými náměty, implementující nové trendy a metody odrážející se ve vzdělávací oblasti Člověk a svět práce.

Námět Počítačem řízené stroje, cesta od nápadu k výrobku autorů Jana Krotkého a Daniela Aichingera (Aichinger a kol., 2017) si klade za cíl mimo jiné implementovat výzkumný nebo lépe vývojový proces do klasické tvorby fyzického výrobku. Schéma námětu je kompatibilní s obrázkem 2 . V první řadě problém je již námětem vymezen, a to $\mathrm{v}$ podobě chybějícího úchytu $\mathrm{k}$ šuplíku. Následně je proces veden přes identifikaci problému, přesný popis problému, hledání hotového řešení (prostor pro zpracování a komparaci informací) k návrhu a ověření vlastního řešení. Než žáci dojdou na konec, musí porovnávat data, kriticky hodnotit a rozhodovat se. Polemizují zda existuje již hotové řešení, jaké jsou požadavky na materiál, jaké technologické operace budou potřebovat atd. Důležitá je vizualizace produktu, která může opět přispět ke zpětné vazbě - ve stádiu návrhu žáci rozpoznají a opraví chybné řešení. Samozřejmě by tento postup neměl zůstat pouze 
u myšlenkového zpracování, ale měl by končit tvorbou fyzického výrobku a hodnocením celého postupu, př́ípadně návrhy na jeho zlepšení - inovaci.

Z hlediska evaluace celého procesu, ale i procesu výuky, se jedná o organizačně složitou záležitost. Týmy žáků jsou během řešení v různých fázích. Učitel je při této aktivitě spíše konzultantem. Vznikají v mnoha ohledech různé výrobky. Nicméně pedagogický přínos v oblasti rozvoje širokého spektra gramotností či přímo klíčových kompetencí (klíčové kompetence ověřujeme v praxi, i když jen simulované) je evidentní.

Podobně jsou koncipované i další náměty. Námět Vytvořme si vlastní stolní hru autorů Jana Fadrhonce a Jana Krále (Aichinger a kol., 2017) představuje širokou technologickou variabilitu řešení a zpracování. Silnou stránkou u této aktivity je motivace a možnost týmové práce. Není direktivně napsané, jak má vypadat hrací pole nebo jak mají vypadat figurky. Námět předkládá možnosti. Je možné zapojit do návrhu grafické programy v počítači, do výroby figurek 3D tiskárnu nebo vše realizovat ,ručně“ pomocí papíru, nůžek a lepidla. Výstupem je opět produkt, ke kterému mají žáci vztah, který jim umožní vyniknout. Důležitým závěrem je prezentace finálního výrobku a demonstrace jeho funkčnosti. V případě uplatnění týmové práce je v procesu prostor pro každého žáka (práce s inkludovanými dětmi nebo s dětmi nadanými).

\section{Diskuse}

Miroslav Staněk (2017) přední český pedagog a popularizátor technického a př́rodovědného vzdělávání upozorňuje ve své přednášce na konferenci Učitel IN na problematiku požadavku vstřebávání velkého množství informací a zároveň potřebě aktivního bádání v podobě požadavku na prožitek, dle moderních pedagogických př́istupů. Neměli bychom se tedy soustředit více na výchovný aspekt vzdělávání než na ten obsahový? Zprostředkovat spíše žákům prožitek na úkor množství informací? Existuje možnost více spolupracovat a směřovat další aktivity do oblasti informálního a neformálního vzdělávání, kde zejména $\mathrm{v}$ tom neformálním vzdělávání existují jak kapacity, tak i dokonce spontánní společenská poptávka.

Ukázali jsme si přizpůsobený životní cyklus školního produktu (obr. 2). Schéma je dostatečně obecné na to, abychom jej mohli aplikovat na většinu produktivních činností pracovního charakteru i na činnosti s využitím např. počítačem řízených strojů. $Z$ praxe opět zaznamenáváme obavy učitelů, že se budou praktické činnosti pozvolna měnit ,jen v práci s počítačem a 3D tiskárnami“. Selena Nemorin (2016) konstatuje a problém identifikuje následovně: ,pokud by technologie $3 D$ tisku byla implementována s cílem nahrazení praktických aktivit, žáci by postrádali bez těchto aktivit (např. klasické ruční obrábění) důležitou zkušenost spojenou s neúspěchem, která se projevuje právě prací při ziskávání zkušenosti pomocí klasických postupư“. Dle našeho názoru model implementace počítačem řízených strojů do vzdělávání na ZŠ je pro následující inovační období zásadní. Existuje celá řada studií i zkušeností, ze kterých se dá vycházet a připravit vhodný koncept pro inovaci kurikula (např. autoři G. Kaiser a B Sriraman, 2006; Kuen-Yi, 2017; C. White, 2017 nebo T. Torrey a R. Maloy, 2017 atd.)

Inovace také musí proběhnout na úrovni přípravy budoucích učitelů (inovace oborových didaktik) i na úrovni dalšího vzdělávání (např. nové kurzy). J. Dostál (2015) si oprávněně klade otázku: ,,...jaké zkušenosti s bádáním ziskaji studenti učitelských oborů, tj. budouci učitelé, a zda jsou dostatečné pro pozdějši uskutečňováni kvalitni badatelsky orientované 
výuky v pedagogické praxi.“ Zkvalitnění praxe budoucích pedagogů lepším propojením s praxí základních škol řeší např́íklad zajímavý koncept pojetí týmové práce vědců a pedagogů kolem Marguse Padaste (2014) z Estonska.

Kvalitní vzdělání stojí peníze. Učitel svým entuziasmem a nasazením je sice zásadním, ale ne jediným faktorem úspěšné změny. Podle Wagnera (2011): „Podle studii UNESCO (2005, s. 17) programy pro rozvoj obecně gramotnosti dostávají v mnoha zemích pouze $1 \%$ z celkového rozpočtu na vzdèláváni."

\section{Závěr}

Uvedenými př́klady z praxe jsme nastínili možnou koncepci inovace aktivit obecně, ale také s ohledem na specifika vzdělávací oblasti Člověk a svět práce. Rozborem vzdělávacích plánů a tvorbou a evaluací výukových materiálů bylo zjištěno, že uvedená oblast má velký potenciál pro stimulaci rozvoje digitální gramotnosti. Požadovaný efekt očekáváme od změny kurikula, které bude plně v souladu s aktuálními trendy. Zároveň jsme identifikovali, že požadavek pro posun našeho školství dalšími a novými směry vychází bezprostředně z aktuálního ekonomického směřování republiky a ze sociopolitické situace. Řešením klíčového celostátního projektu „Digitální gramotnost“ v následujících třech letech Ministerstvo školství očekává jasné podněty ze strany akademických pracovníků pedagogických fakult a učitelů z praxe.

Závěrem, Androulla Vassiliou, Evropský komisař pro vzdělávání a kulturu uvádí: "Vylepšené digitálni dovednosti a přistup $k$ digitálním a otevřeným zdrojuim jsou rozhodujicí nejen pro lepši výuku, ale také pro vytváření flexibilnich vzdělávacích modelü, které ulehčuji celoživotni učeni."

\section{Literatura}

Aichinger, D., Brändle M., Ekkert F., Fadrhonc J., Heller K., Honzíková J., Honzík L., Horlacher B., Hrdlička J., Jurich N., Kanta T., Korálová E., Kraitr M., Král J., Kranzinger F., Krotký J., Liß J., Prchlík J.., Richtr V., Simbartl P., Spurk M., Štich L., Štrofová J., Tomisová K., \& Trein H. M. (2017) Technika - Metodická př́ručka pre učitel'a vzdelávacej oblasti Člověk a svet práce na 2. stupni ZŠ, Dr. Josef Raabe, s.r.o., Bratislava, Slovensko. p. 752

Bartoň, A. (2017). Perspectives of technical education development for students with mild mental disabilities. Journal Of Technology And Information, 9(2), 48-60. http://dx.doi.org/10.5507/jtie.2017.010

Braňka, J. (2010). Požadavky českého trhu práce na technické obory. Praha: Národní vzdělávací fond, o.p.s.

Calvani, A., Cartelli, A., Fini, A., \& Ranieri, M. (2008). Models and Instruments for assessing Digital Competence at School. Journal Of E-Learning And Knowledge Society, 4(3), 183-193.

Callahan, C., Tomlinson, C., Hunsaker, S., Bland, L., \& Moon, T. (1995). Instruments and evaluation designs used in gifted programs. Storrs: University of Connecticut, The National Research Center on the Gifted and Talented.

Český statistický úrad. (2015). Hodnocení výkonnosti ekonomiky České republiky v širším kontextu. Retrieved 11 April 2017, from https://www.czso.cz/csu/czso/cri/hodnocenivykonnosti-ekonomiky-ceske-republiky-v-sirsim-kontextu 
Česká školní inspekce. (2015). Metodika pro hodnocení rozvoje informační gramotnosti. (p. 10). Praha.

Digital Literacy - 21 st. Century Competence for Our Age. (2015). Ministry for Education and Employment (p. 18). Malta.

Doorman, M., Jonker, V., \& Wijers, M. (2016). Matematika a prírodní vědy pro život: badatelský orientovaná výuka a svět práce (p. 99). Hradec Králové: Gaudeamus.

Dostál, J. (2015). Inquiry-based instruction and teacher's competences for its realization. Journal Of Technology And Information, 7(1). http://dx.doi.org/10.5507/jtie.2015.001

Dostál, J., \& Prachagool, V. (2016). Technology education at a crossroads - history, present and perspectives. Journal of Technology And Information, 8(2). http://dx.doi.org/10.5507/jtie.2016.006

Draxal, L. (2017). Praktická část diplomové práce Rozvoj technických kompetencí žáka. In Olympiáda techniky Plzeň 2016 (pp. 249-254). Plzeň: ZČU v Plzni.

Eyre, M. (2017). Digital literacy in the classroom. How important is it? . Retrieved 20 May 2017, from http://resourced.classflow.co.uk/digital-literacy-classroom-important/

Ferrari, A. (2013). DIGCOMP: A Framework for Developing and Understading Digital Competence in Europe (p. 50). Luxembourg: JRC Scientific and Policy Reports, European Commission.

Gilster, P. (1997). Digital literacy. 1st ed. New York: John Wiley \& Sons.

Grech, A. (2014). National Lifelong Learning Strategy 2020. Malta: Ministry for Education and Employment.

Hejnová, E., \& Hejna, D. (2016). Rozvoj vědeckého myšlení žáků prostřednictvím př́rodovědného vzdělávání. Scientia In Educatione, 7(2), 2-17.

Horizon Report urges schools to tackle 'wicked' digital skills challenge. (2014). Retrieved 20 April 2017, from http://europa.eu/rapid/press-release_IP-14-1075_en.htm

Krátký, J. (2015). Práce v dillnách: Inspirace pro učitele, 50 pracovních námètů pro žáky 6.-9. třid.

Krotký, J., Korytář, J., \& Simbartl, P. (2016). Interdisciplinary Approach to Technical Education. Edukacja -Technika - Informatyka, 17(3), 82-88.

Mařík, V. (2015). Národní iniciativa Průmysl 4.0 (p. 23). Praha: Ministerstvo průmyslu a obchodu.

Mach, P., Simbartl, P., \& Krotký, J. (2015). Průzkum a vyhodnoceni dotazníkového šetření, Projekt World of Work (WoW). World of Work - Aktivita 1. Retrieved 18 May 2017, from http://www.world-of-work.eu/sites/default/files/documents/Research_report_CZ.pdf Ministerstvo práce a sociálních věcí (MPSV). (2014). Strategie politiky zaměstnanosti do roku 2020. (p. 50). Praha.

Ministerstvo práce a sociálních věcí (MPSV). (2015). Analýza vývoje zaměstnanosti a nezaměstnanosti v roce 2015. (p. 107). Praha.

Národní ústav pro vzdělávání (NÚV). (2017). Rámcový vzdělávací program pro základní vzdělávání. (p. 165). Praha.

Nemorin, S. (2016). The frustrations of digital fabrication: an auto/ethnographic exploration of ,,3D Making " in school. International Journal of Technology and Design Education. Advance online publication, doi: 10.1007/s10798-016-9366-z

New Vision for Education: Fostering Social and Emotional Learning through Technology. (2017). World Economic Forum 2016. Retrieved 18 May 2017, from http://www3.weforum.org/docs/WEF_New_Vision_for_Education.pdf 
Němeček, J. (2017). JPMorgan vyřadi Česko z vyspělých zemí. Neplníme př́jem na hlavu. Patria.cz. $\quad$ Retrieved 22 June 2017, from https://www.patria.cz/zpravodajstvi/3460449/jpmorgan-vyradi-cesko-z-vyspelych-zemineplnime-prijem-na-hlavu.html

Pedaste, M., Pedaste, K., Lukk, K., Villems, P., \& Allas, R. (2013). A model of innovation Scholls: Estonian case-study. Procedia - Social And Behavioral Sciences, 112(2014), (pp. 418-427).

Rasinen, A., Virtanen, S., Endepohls-Ulpe, M., Ikonen, P., Ebach, J., \& Stahl-von Zabern, J. (2009). Technology education for children in primary schools in Finland and Germany: different school systems, similar problems and how to overcome them. International Journal Of Technology And Design Education, 19(4), 367-379. http://dx.doi.org/10.1007/s10798-009-9097-5

Staněk, M. (2017). „BOV“, „STEAM“ a „Polytechnická výchova“. Novinky v českém školství? Konference Učitel In, 14. 10. 2017, Plzeň

Spitzer, M. (2014) Digitální demence. translating by. František Ryčl, Host, (p. 343). Brno. Szabó, K. (2016). Reading from screen - About the problem of developing online educational texts regarding the special ways of online reading strategies. In 11th International Conference on Towards Open Education and Information Society (pp. 7889). Prague.

Sefton-Green, J., Nixon, H., \& Erstad, O. (2009). Reviewing Approaches and Perspectives on "Digital Literacy". Pedagogies: An International Journal, 4(2), 107-125. http://dx.doi.org/10.1080/15544800902741556

Teichler, U. (2009). Higher Education and the World of Work, Conceptual Frameworks, Comparative Perspectives, Empirical Findings. Global perspectives on Higher Education (p. 37). Kassel: International Centre for Higher Education Research.

UNESCO. International Journal Of Educational Development, 31(3), 319-323.

UNESCO EFA Global Monitoring Report: Literacy for life. (2005) (p. 448). Paris.

Vanderlinde, R., \& Van Braak, J. (2010). The e-capacity of primary schools: Development of a conceptual model and scale construction from a school improvement perspective. Computers \& Education, 55(2), 541-553.

Wagner, A. (2011). What happened to literacy? Historical and conceptual perspectives on literacy in UNESCO. International Journal Of Educational Development, 31(3), 319-323. What are funkcional Skills? (2016). ForSkills. Retrieved 14 April 2017, from http://www.forskills.co.uk/what-are-functional-skills/ 